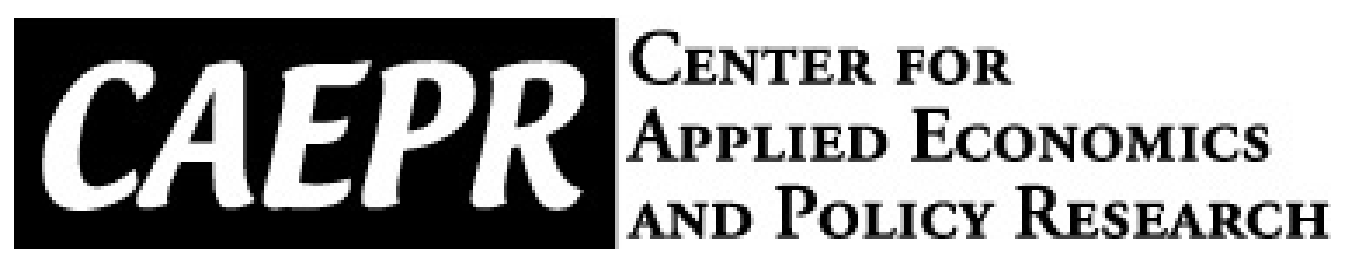

CAEPR Working Paper

\#007-2010

\title{
Sovereign Default Risk Premia, Fiscal Limits and Fiscal Policy
}

\author{
Huixin Bi \\ Indiana University
}

May 24, 2010

This paper can be downloaded without charge from the Social Science Research Network electronic library at: http://ssrn.com/abstract=1616801.

The Center for Applied Economics and Policy Research resides in the Department of Economics at Indiana University Bloomington. CAEPR can be found on the Internet at:

http://www.indiana.edu/ caepr. CAEPR can be reached via email at caepr@indiana.edu or via phone at 812-855-4050.

( 2008 by NAME. All rights reserved. Short sections of text, not to exceed two paragraphs, may be quoted without explicit permission provided that full credit, including $\odot$ notice, is given to the source. 


\title{
Sovereign Default Risk Premia, Fiscal Limits and Fiscal Policy
}

\author{
Huixin $\mathrm{Bi}^{*}$
}

May 24, 2010

\begin{abstract}
We develop a closed economy model in order to study the interactions among sovereign risk premia, fiscal limits and fiscal policy. The stochastic fiscal limit, which measures the ability and willingness of the government to service its debt, arises endogenously from dynamic Laffer Curves. The distribution of fiscal limits is countryspecific, depending on the size of the government, the degree of the counter-cyclical policy responses, economic diversity and political uncertainty, and, therefore, the model can rationalize different sovereign ratings across developed countries. The model also produces a nonlinear relationship between sovereign risk premia and the level of government debt. The nonlinearity is consistent with the empirical evidence that once risk premia begin to rise, they do so rapidly. The default risk premia of long-term bonds jump ahead of short-term bonds and provide early warnings of sovereign defaults.

JEL Classification: E62; H30; H60
\end{abstract}

*I am deeply grateful to my advisor, Eric Leeper, for his constant encouragement and thoughtful advice. I am indebted to Troy Davig for his advice and support throughout this project. I also thank R. Anton Braun, Brian Peterson, David Romer, Andreas Schabert, Juergen von Hagen and Todd Walker for many useful suggestions. All errors are mine. Department of Economics, Indiana University, hbi@indiana.edu. 


\section{INTRODUCTION}

As a result of the deterioration of public finances in tandem with mounting economic pressure from the financial crisis, rating agencies downgraded the sovereign debt in several OECD countries in 2009 and 2010. Portugal and Spain were downgraded by one notch, while Ireland and Greece were downgraded by two notches. The spread between the 10-year Greek government bond and equivalent German bond widened to more than 300 basis points in March 2010. Contrary to conventional wisdom, developed countries are frequently penalized when the financial market raises concerns about the risk of government debts, even though these countries have not defaulted on their sovereign debt in the post-war period. Figure 1 depicts the sovereign downgrades of OECD countries since 1975. In addition, different countries are usually downgraded at different levels of debt. Figure 2 compares six countries in three groups, New Zealand and Canada, Italy and Belgium, and Sweden and Japan. For instance, the debt rating of the government of New Zealand was reduced by three notches from AAA to AA- as its gross debt climbed from $58 \%$ to $75 \%$ of its GDP. The Canadian government, on the other hand, was able to keep its AAA rating until its debt hit $90 \%$ of its GDP. These evidences indicate that the joint analysis of sovereign default risk premia and fiscal policy behavior is an important line of theoretical work.

We consider a closed economy in which the government finances an exogenous level of purchases and counter-cyclical lump-sum transfers to households by collecting distorting taxes and issuing non-state-contingent bonds. However, the bond contract is not enforceable. The maximum level of debt that the government is able and willing to service, which we will call fiscal limit, is constrained by dynamic Laffer Curves and political willingness. Dynamic Laffer Curves, endogenously arising from distorting taxes, constrain the government's ability to service its debt. If the tax rate is on the slippery side of Laffer Curve, then the government would be unable to raise more tax revenue through a higher tax rate. Even if the government is able to raise tax revenue, it may not be willing to do so. We treat the willingness as a political decision unrelated to economic fundamentals.

The fiscal limit is stochastic. At each period, an effective fiscal limit is drawn from the distribution. If the level of government debt surpasses the effective fiscal limit, then the government reneges on a fraction of its debt. Households are assumed to know the distribution of the fiscal limit. Using this information, they can decide the quantity of government bonds that they are willing to hold and the price at which they are willing to purchase the bonds.

First, we find that the distribution of fiscal limits is country-specific and depends on the 
underlying macroeconomic fundamentals. An economy that is less vulnerable to exogenous shocks may allow the government to raise tax revenue without moving into the slippery side of the Laffer Curve. A government with a heavy burden of lump-sum transfers or government purchases has a higher probability of reaching the peak of the Laffer Curve and may face a significantly lower fiscal limit. Strong counter-cyclical transfers, which arise from large automatic stabilizers or discretionary counter-cyclical fiscal policies, can lead to a more dispersed distribution of fiscal limits, as they deteriorate government budgets when tax revenue is low. In addition, the distribution also hinges on political willingness to service debt. Higher political risk may reduce the fiscal limit. We calibrate the model to three groups of countries, Canada and New Zealand, Belgium and Italy, and Japan and Sweden, and find that the predicted distributions of fiscal limits are consistent with the observed sovereign downgrades in these countries, as illustrated in Figure 2.

Second, the default risk premium, reflecting the probability of sovereign default, is a nonlinear function of the level of the government's debt. The risk premium begins to emerge as the level of the debt approaches the lower end of the distribution of the fiscal limit. The nonlinearity between the sovereign risk premia and government indebtedness is widely identified in empirical literature, (see Alesina et al. (1992), Bernoth et al. (2006) and among many others). We also find that the default risk premia of the long-term bonds jump ahead of the short-term bonds and provide early warnings of sovereign defaults. Under a plausible calibration to the economy of Greece, the model predicts sovereign risk premia comparable to those observed in the data.

This paper is closely related to Uribe (2006). In a closed economy model with nominal debt and an exogenous tax policy, Uribe (2006) shows that default is inevitable if the monetary authority follows price-level targeting, as both monetary and fiscal policy are 'active' in the sense of Leeper (1991). He solves the model analytically by assuming that the government has to default when the tax-to-debt ratio falls below some fixed and exogenous threshold. Using a real economy model, Juessen et al. (2009) endogenize the defaulting threshold by introducing the Laffer Curve and assuming that investors may stop lending whenever the government runs into a Ponzi scheme. However, the tax policy is assumed to be exogenous in order to endogenize the defaulting threshold. After solving the model using a second-order approximation, they show that under plausible calibrations, the predicted sovereign risk premia fall far short of those observed in the data.

We contribute to the literature in three dimensions. First, we allow for an endogenous fiscal limit. The effective fiscal limit is a random draw from the distribution of fiscal limits, which endogenously arise from the dynamic Laffer Curves. The predicted distributions of fiscal limits for different countries are consistent with sovereign downgrades in the OECD 
countries. Second, we allow for an endogenous tax policy, which allows the government to raise the tax rate when government debt rises and, therefore, to affect the outcome of sovereign default. Otherwise, the sovereign default only depends on exogenous shocks or parameters. Third, we solve the full nonlinear model using the Monotone Mapping method. The nonlinear solution is important since the fiscal limit can be far from the steady state.

A large amount of theoretical literature exists that considers sovereign default in emerging market economies. Following Eaton and Gersovitz (1981) and Arellano (2008), this literature uses a small open economy model and assumes that the government, being a benevolent social planner, makes an optimal and strategic decision of sovereign default. In this paper, we do not model the sovereign default as a strategic decision as we try to understand the different sovereign risk premia across developed countries where sovereign defaults have rarely occurred in the post-war period.

\section{INFINITE-HORIZON MODEL}

In this section, we lay out an infinite-horizon model in which fiscal limits, which measure the government's ability and willingness to service its debt, arise endogenously from dynamic Laffer Curves. Consider a closed economy with linear production technology. The aggregate resource constraint is,

$$
c_{t}+g_{t}=A_{t}\left(1-L_{t}\right)
$$

where the level of productivity $\left(A_{t}\right)$ follows an $A R(1)$ process,

$$
\ln \frac{A_{t}}{A}=\rho^{A} \ln \frac{A_{t-1}}{A}+\varepsilon_{t}^{A} \quad \varepsilon_{t}^{A} \sim \mathcal{N}\left(0, \sigma_{A}^{2}\right)
$$

Government: The government finances lump-sum transfers to households $\left(z_{t}\right)$ and exogenous and unproductive purchases $\left(g_{t}\right)$ by collecting tax revenue and issuing one-period bonds $\left(b_{t}\right)$. Tax revenue is raised through a time-varying tax rate $\left(\tau_{t}\right)$ on labor income.

$$
\tau_{t} A_{t}\left(1-L_{t}\right)+b_{t} q_{t}=\underbrace{\left(1-\Delta_{t}\right) b_{t-1}}_{b_{t}^{d}}+g_{t}+z_{t}
$$

$q_{t}$ is the price of the bond in units of time $t$ consumption. For each unit of bond, the government promises to pay the household one unit of consumption in the next period. However, the bond contract is not enforceable. At time $t$, the government may partially default on its liability $\left(b_{t-1}\right)$ by a fraction of $\Delta_{t}$. The post-default government liability is denoted as $b_{t}^{d}$. The default scheme depends on the distribution of the fiscal limit, which arises endogenously from dynamic Laffer Curves. Section 2.1 provides a further discussion 
of the fiscal limit and the default scheme.

We assume that the government follows a simple tax rule. It is an abstraction designed to capture the tax policy as fiscal authorities tend to increase the tax rate when government debt rises. We refer to the parameter of $\gamma$ as the "tax adjustment parameter" $(\gamma>0)$. A larger $\gamma$ means that the government is more willing to retire debt by raising the tax rate.

$$
\tau_{t}-\tau=\gamma\left(b_{t}^{d}-b\right)
$$

In addition, we assume that lump-sum transfers are countercyclical. This assumption follows from the estimation that the elasticity of real detrended transfers with respect to detrended productivity $\left(\zeta^{z}\right)$ is negative for all of the OECD countries, varying from -0.093 to -2.22. On the other hand, the estimated elasticity of real government purchases with respect to productivity isn't conclusive, varying from +2.5 to -2.5 across the OECD countries. In this paper, we treat the government purchases as an exogenous shock which follows an $A R(1)$ process.

$$
\begin{aligned}
& \ln \frac{z_{t}}{z}=\zeta^{z} \ln \frac{A_{t}}{A} \quad \zeta^{z}<0 \\
& \ln \frac{g_{t}}{g}=\rho^{e} \ln \frac{g_{t-1}}{g}+\varepsilon_{t}^{g} \quad e_{t} \sim \mathcal{N}\left(0, \sigma_{e}^{2}\right)
\end{aligned}
$$

Household: With access to the sovereign bond market, a representative household chooses consumption, leisure and bond purchases according to,

$$
\begin{gathered}
\max \quad E_{0} \sum_{t=0}^{\infty} \beta^{t} u\left(c_{t}, L_{t}\right) \\
\text { s.t. } \quad A_{t}\left(1-\tau_{t}\right)\left(1-L_{t}\right)+z_{t}-c_{t}=b_{t} q_{t}-\left(1-\Delta_{t}\right) b_{t-1}
\end{gathered}
$$

with prices and policies, $\left\{\tau_{t}, z_{t}, q_{t}, \Delta_{t}\right\}$, taken as given. $E_{t}$ is the mathematical expectation that is conditional on the information available at time $t$, including the sovereign default information. $\beta$ is the discount factor, while $u(c, L)$ is strictly increasing in terms of household consumption and leisure.

The household's first-order condition requires that the marginal rate of substitution between consumption and leisure equates to the after-tax wage. The government bond price in Equation 10 reflects the household's expectation about the probability and magnitude of 
sovereign default in the next period.

$$
\begin{aligned}
\frac{u_{L}(t)}{u_{c}(t)} & =A_{t}\left(1-\tau_{t}\right) \\
q_{t} & =\beta E_{t}\left(\left(1-\Delta_{t+1}\right) \frac{u_{c}(t+1)}{u_{c}(t)}\right)
\end{aligned}
$$

The optimal solution to the household's maximization problem must also satisfy the following transversality condition,

$$
\lim _{j \rightarrow \infty} E_{t} \underbrace{\beta^{j+1} \frac{u_{c}(t+j+1)}{u_{c}(t)}}_{Q_{t+j+1}} \underbrace{\left(1-\Delta_{t+j+1}\right) b_{t+j}}_{b_{t+j+1}^{d}}=0 .
$$

$Q_{t+j+1}$ is the stochastic discounted factor from time $t$ to time $t+j+1$.

2.1 Fiscal Limit and Laffer Curve The proportional tax on labor income distorts a household's behavior as it lowers the after-tax wage and may induce household to work less. An increase in the tax rate on labor income may or may not raise tax revenue depending on the existing tax rate. In general, higher rates raise revenue when the existing tax rate is low and reduce revenue when the existing rate is high, which is the basis for the Laffer Curve. Laffer Curves are usually dynamic in the sense that the shape of the Laffer Curve depends on the state of the economy, i.e, the productivity level $\left(A_{t}\right)$ and government purchases $\left(g_{t}\right)$ in our model. ${ }^{1}$

For a given state, a tax rate exists at that higher rates do not raise more revenue. This point is the peak of the dynamic Laffer Curve, denoted as $\tau^{\max }(A, g)$. At this point, the government can raise the maximum level of fiscal surplus, because the government purchases are an exogenous state and the lump-sum transfers are countercylical. The ceiling of the fiscal surplus constrains the maximum level of debt that the government is able to pay back. Mathematically, it is the expected sum of the discounted maximum fiscal surplus in all future periods. $^{2}$

However, the government may not be willing to tax the labor income at the peak of Laffer Curve in practice depending on complicated political considerations. Poor's (2008) states that "the stability, predictability, and transparency of a country's political institutions are important considerations in analyzing the parameters for economic policymaking."

Without resorting to a structure political economy model, we introduce a political risk

\footnotetext{
${ }^{1}$ Trabandt and Uhlig (2009) use a neoclassical model to compute Laffer Curves for the United States and 15 European countries.

${ }^{2}$ Cochrane (2010) emphasizes the fiscal limit to monetary policy in the discussion of monetary and fiscal policy in the financial crisis of 2008-2009.
} 
parameter $(\theta)$ into the model. Higher political risk (a lower $\theta$ ), as a result of a lack of political consensus or a turnover of power across political parties with different ideologies, implies a lower probability for the government to raise fiscal surplus at the maximum level. We assume that the maximum fiscal surplus that the government is willing to raise is proportional to the value of $\theta$. For a given state of the economy $\left(A_{t}, g_{t}\right)$, the maximum primary fiscal surplus that government is willing to raise $\left(s_{t}^{\max }\right)$ depends on the political risk in the following way,

$$
s_{t}^{\max }=\theta\left(T_{t}^{\max }-g_{t}-z_{t}\right) \quad 0 \leq \theta \leq 1 .
$$

Equation 12 implies that the government simply rolls over its debt and the primary fiscal surplus is zero if the political risk is extremely high and $\theta$ is zero. On the other hand, the government is willing to raise the maximum fiscal surplus if the political risk is extremely low and $\theta$ is one.

To this end, we can define the fiscal limit as the maximum level of debt that the government is able and willing to service. If the political risk is time-varying, then the fiscal limit can be written as,

$$
\mathcal{B}^{*}=E_{0} \sum_{t=0}^{\infty} Q_{t}^{\max } \theta_{t}\left(T_{t}^{\text {max }}-g_{t}-z_{t}\right)
$$

$Q^{\max }$ and $T^{\max }$ represent the discounted rate and total tax revenue when the tax rate is at the peak of Laffer Curve $\tau^{\max }$. Appendix A describes how to generate the distribution of the fiscal limit through a Markov Chain Monte Carlo simulation. The distribution is approximated to $\mathcal{N}\left(b^{*}, \sigma_{b}^{2}\right)$.

2.2 Default Scheme The default scheme depends on the realization of the effective fiscal limit $\left(b_{t}^{*}\right)$, which is a random draw from the distribution of fiscal limit. If the debt surpasses the effective fiscal limit, then the government partially defaults. The assumption of a partial default and random draws from the distribution is an abstraction from debt renegotiation. Looking at comprehensive historical data, Reinhart and Rogoff (2009) show that creditors can often get a significant share of what they are owed after contentious debt negotiations.

We assume that the default rate $(\delta)$ depends on the distribution of fiscal limit in the following way,

$$
\Delta_{t}= \begin{cases}0 & \text { if } b_{t-1}<b_{t}^{*} \\ \delta \equiv \frac{2 \sigma_{b}}{b^{*}} & \text { if } b_{t-1} \geq b_{t}^{*}\end{cases}
$$

The larger the standard deviation $\left(\sigma_{b}\right)$, the higher the default rate becomes. A more dispersed 
distribution of the fiscal limit implies a higher uncertainty of the government's ability and willingness to service its debt. If the government debt equals the mean of the distribution $b^{*}$, then the government would default enough to bring the debt level below the lower boundary

of the fiscal limit, defined as two standard deviations below the mean $\left(b^{*}-2 \sigma_{b}\right)$, and, therefore, the probability of sequential defaults would be low. This assumption is meant to capture the fact that defaults in sequential periods are not frequently observed.

2.3 Fiscal Limit and Transversality Condition It is important to emphasize that the fiscal limit, defined in Equation (13), is independent of the equilibrium conditions of the model. Given the structural parameters of the model and the specification of the shock processes, the unique mapping between $\tau^{\max }$ and the state of the economy $(A, g)$ determines the distribution of the fiscal limit, regardless of the equilibrium conditions of the model.

A natural question that one may ask is, "Why not to define sovereign default as the consequence that occurs if the government becomes unable to avoid a Ponzi scheme?" If we follow this approach, then either the government never defaults in equilibrium, or no equilibrium exists, because the time-varying tax rate endogenously depends upon the level of government debt as specified in Equation (4). If the tax adjustment parameter is sufficiently large, then the government never defaults. However, if the tax adjustment parameter is too small, then no equilibrium exists.

In related literature, Uribe (2006) applies simple closing rules in the sense that the government defaults when the current tax-to-debt ratio exceeds a fixed and exogenous ratio. Juessen et al. (2009) assume that the tax rate is constant and, therefore, government default can occur in equilibrium.

\section{Distribution of Fiscal Limit}

The distribution of the fiscal limit is country-specific and depends on the underlying parameters, for instance, of political uncertainty, counter-cyclicality of lump-sum transfers, the government size and shock processes, as shown in Equation 13. In Section 3.2, we calibrate the model to a 'typical' OECD country in the sense that all of the parameters are set to the average of the OECD data. Then we change one parameter at a time and compare the distributions in order to understand how each parameter affects the distribution. In Section 3.3 we move a step further by calibrating the simple model to six different countries in three groups, Canada and New Zealand, Belgium and Italy, and Japan and Sweden. We compare the predicted distributions of fiscal limits in order to discover whether they are consistent with the observed sovereign downgrades. 
3.1 Benchmark Calibration The model is calibrated at an annual frequency. The household discount rate is 0.95 and the net interest rate is $5.26 \%$. The utility function is assumed to be $u(c, L)=\log c+\phi \log L$. The leisure preference parameter $(\phi)$ is calibrated in such a way that the household spends $25 \%$ of time working and the Frisch elasticity of labor supply is 3 . The total amount of time and the productivity level at the steady state are normalized to 1 .

Other parameters may vary across different experiments. Following Arteta and Galina (2008), we use the International Country Risk Guide's (ICRG) index of political risk to calibrate the parameter of $\theta$. The ICRG index at the scale of 0 to 100 has been available since 1984. The higher the ICRG index, the lower the political risk. We calibrate $\theta$ to ICRG index scaled by 100 .

All of the fiscal variables are calibrated to the data for the period between 1971 and 2007 from the OECD Economic Outlook No. 84 (2009). The average tax rate is defined as the ratio of the total tax revenue over the GDP, including social security, indirect and direct taxes. The total government purchases include government consumption of fixed capital and government final consumption of expenditures. Lump-sum transfers are defined as the sum of the social security payments, net capital transfers and subsidies. The shock process of productivity is estimated using the detrended data of the real GDP per worker. ${ }^{3}$ In addition, the elasticity of lump-sum transfers with respect to productivity $\left(\zeta^{z}\right)$ is estimated through linear regression of the detrended real lump-sum transfers over the detrended real GDP per worker.

We simulate the distributions of fiscal limits using Markov Chain Monte Carlo method, following the steps in Appendix A.

3.2 General Comparison In the benchmark case, we calibrate the simple model to a 'typical' OECD country. Taken the government purchase-GDP ratio for instance. We calculate the overall average ratio of government purchase over GDP during the period of 1971 to 2007 and across all countries. In the benchmark calibration, $g / y$ is set to this overall average ratio.

In the same period, the average lump-sum transfers are $15.7 \%$ of the GDP, the average government purchases are $21.3 \%$ of the GDP, and the average tax rate is 0.362 . The average estimation of $\zeta^{z}$ is -0.947 , implying that a decrease of productivity by $10 \%$ raises the lumpsum transfers by $9.47 \%$. Using a Hodrick and Prescott (1997) filter, both the productivity and the government purchase shocks have an average persistence of 0.553 and an average standard deviation of 0.02 . The ICRG index of political risk stays fairly stable across time

\footnotetext{
${ }^{3}$ The data of real GDP per worker is from Penn World Table Version 6.2, see Heston et al. (2006).
} 
for most of the OECD countries and, therefore, we let $\theta_{t}$ fixed across time and calibrate according to the average ICRG index, which is 83 .

We then change one parameter at a time in order to understand how the different parameters affect the distribution of fiscal limits.

Government Size: The highest average share of government purchases over the GDP is $29 \%$ in Sweden and the lowest average share is $13.7 \%$ in Switzerland. The average is $21.3 \%$ across all of the OECD countries. In the top left panel of Figure 3, we keep all of the other variables the same as in the benchmark case, but vary the share of government purchases over the GDP from $29 \%$ to $21.3 \%$ and $13.7 \%$. The variance of the distribution doesn't change much, but the mean rises dramatically from $30 \%$ of the GDP to $235 \%$ of the GDP. This increase is due to higher government purchases, which can reduce the maximum feasible fiscal surplus at each period and significantly lower the fiscal limit. Similar dramatic changes are observed in the top right panel of Figure 3, as the lump-sum transfers change from $22.4 \%$ of the GDP (Austria) to $15.7 \%$ (the benchmark case) and $8.4 \%$ (Australia).

Countercyclical Lump-sum Transfers: In the left panel of the second row, we let $\zeta^{z}$ change from -2.22 (Sweden) to -0.947 (the benchmark case) and -0.093 (Austria), while keeping the other parameters at the overall average across the countries. The mean of the distribution doesn't change, but the standard deviation is almost double from 0.0076 to 0.017. Strong countercyclical fiscal transfers, arising from a large automatic stabilizer or discretionary countercyclical policy, can aggravate the volatility of the fiscal limit. In a bad state with lower productivity, the government transfers more resources to households and the budget is further deteriorated.

Political Risk: In the right panel of the second row, when $\theta$ decreases from 0.96 (Netherland) to 0.83 (the benchmark case) and 0.59 (Greece), the mean of the distribution decreases from $151 \%$ of the GDP to $130 \%$ and $93 \% .{ }^{4}$ A lower political risk (a higher $\theta$ ) indicates that the government is more willing to service its debt.

Shock Process: In the third row of Figure 3, we compare distributions when the persistence and standard deviation of the productivity shock change. The shock persistence varies from 0.747 (Spain) to 0.553 (the benchmark case) and 0.342 (Italy) in the left panel, while the standard deviation changes from 0.034 (New Zealand) to 0.02 (the benchmark case) and

\footnotetext{
${ }^{4}$ The ICRG index of political risk is quite stable over time for OECD countries. The highest index in the sample is from Netherland in 2001, and the lowest is from Greece in 1986.
} 
0.014 (France) in the right panel. The standard deviation of the distribution is reduced from 0.019 to 0.008 in both comparisons. The economy may face a dispersed distribution of fiscal limits if the productivity shock is more persistent or volatile.

The shock persistence varies from 0.726 (Canada) to 0.553 (the benchmark case) and 0.2 (Denmark) in the left panel of the bottom row, while the standard deviation changes from 0.0288 (Ireland) to 0.02 (the benchmark case) and 0.0147 (France) in the right panel. However, the distribution of fiscal limits does not drastically change. This conclusion is model-specific. Due to the logarithmic utility function of leisure, the wealth and substitution effects from a change of government purchases are almost canceled out.

3.3 Country Analysis In this section, we calibrate our model to three groups of countries, Canada and New Zealand, Belgium and Italy, and Japan and Sweden, so that we can compare the predicted distributions of fiscal limits to the observed sovereign downgrades.

3.3.1 Canada vs. New Zealand Canada and New Zealand are very similar in terms of average tax rates (32.4\% in Canada and 31\% in New Zealand), average government spending shares (23\% of the GDP in Canada and $20.5 \%$ in New Zealand) and average transfer shares ( $12 \%$ of the GDP in Canada and $13.4 \%$ in New Zealand). The estimated elasticities of lump-sum transfers with respect to productivity are also comparable for the two countries (-1.25 for Canada and -0.82 for New Zealand). The average ICRG indexes of political risk are almost identical (84.1 in Canada and 85.3 in New Zealand).

However, the two countries have been treated differently by the rating agencies, as illustrated in the top row of Figure 2. From 1983 to 1992, the debt rating of New Zealand government was reduced by three notches from AAA to AA- as its gross debt climbed from $58 \%$ to $75 \%$ of the GDP. The Canadian government, on the other hand, was able to keep its AAA rating until its gross debt hit $91 \%$ of the GDP in 1992. The rating was reduced by one notch to AA+ and then stayed at this level until 2001.

An important reason for this discrepancy is that the economy of New Zealand is less diversified than Canada. For instance, Standard \& Poor's sees New Zealand economy's structure as relatively narrowly-based and heavily reliant on agriculture as it reports that agriculture accounted for close to $7 \%$ of New Zealand's GDP and 58\% of its export receipts. This type of economic structure makes New Zealand particularly vulnerable to international commodity price fluctuations and global economic slowdowns. During the period between 1970 and 2007, the standard deviation of the detrended real GDP per worker in New Zealand is about twice as large as that of Canada.

We simulate the distributions of fiscal limits for both countries following Equation 13. In order to illustrate the impact of the variance of the productivity shock upon the distribution, 
we keep all the other parameters the same for two countries. The average tax rate is set to 0.32 , average government spending-GDP ratio to 0.21 , average transfer-GDP ratio to 0.13 , average political uncertainty to 0.85 and the elasticity of transfers with respect to productivity to -1.25 . The standard deviation of the productivity shock is estimated to be 0.04 in New Zealand and 0.02 in Canada, while the persistence is estimated to 0.6 for both countries. Since the shock process of the government purchases does not have much of an impact on distribution, we let it be constant.

The top panel of Figure 4 shows that the distribution of the fiscal limit is much more dispersed in New Zealand than in Canada. Given the same level of government debt, a less diversified economy is more vulnerable to exogenous shocks and may face tighter fiscal restrictions.

3.3.2 Belgium vs. Italy Both Italy and Belgium accumulated massive public debt in the 1990s, well above $100 \%$ of the GDP, as shown in the middle row of Figure 2. However, only the Italian government received persistent downgrades, while Belgium's rating has been stable. One possible explanation is that Belgium demonstrated strong political willingness to be fiscal responsible. It made great strides in reforming the welfare program and reducing lump-sum transfers by about $10 \%$ of the GDP since 1980. On the contrary, a high level of public debt has been sustained in Italy since 1980 in spite of fiscal consolidation attempts that have occurred periodically in the country since the early 1990s.

The two countries are very similar in regard to average transfer shares $(18.8 \%$ of the GDP in Belgium and $17.8 \%$ of the GDP in Italy) and the estimated elasticity of transfers with respect to productivity (-0.63 in Belgium and -0.73 in Italy). The processes of productivity shocks feature similar standard deviations (0.018 in Belgium and 0.017 in Italy) and fairly comparable persistence (0.31 in Belgium and 0.53 in Italy). They are also fairly comparable in terms of average tax rates (0.43\% in Belgium and $0.36 \%$ in Italy) and average government spending shares (23.8\% of the GDP in Belgium and 20\% of the GDP in Italy). However, the average ICRG index of political risk is lower in Italy than in Belgium (around 70 in Italy and 80 in Belgium) during the period between 1988 and 1995 when the Italian government bond was downgraded.

In the simulation, the average tax rate is set to 0.4 , average government spending-GDP ratio to 0.225 , average transfer-GDP ratio to 0.18 and the elasticity of transfers with respect to productivity to -0.7 . The standard deviation of the productivity shock is set to 0.018 and the persistence to 0.5 . The shock process of government purchases is almost identical in the two countries with a standard deviation of 0.025 and persistence of 0.68 . The parameter of political risk, nevertheless, is calibrated at 0.7 in Italy and 0.8 in Belgium. 
The middle panel of Figure 4 shows that the mean of the distribution of fiscal limit is lower in Italy than in Belgium. A lack of political will to act on the deterioration of public finances raises political uncertainty and is often an important factor in sovereign downgrades.

3.3.3 Japan vs. Sweden The comparison of Japan and Sweden sheds some light on how the size of a government and counter-cyclical transfers affect the distribution of the fiscal limit. The two countries are similar in terms of political risk, with an average ICRG index of 84 in Japan and 86 in Sweden. The estimated processes of productivity shocks are comparable. The persistence is 0.56 in Japan and 0.66 in Sweden, and the standard deviation is 0.018 in Japan and 0.015 in Sweden. However, the two countries are very different in terms of average tax rates (26\% in Japan and $49 \%$ in Sweden), average government spending shares (16.2\% of the GDP in Japan and 29\% in Sweden), average transfer shares (10\% of the GDP in Japan and $19.5 \%$ in Sweden) and the elasticities of the transfers with respect to productivity (-1.15 in Japan and -2.22 in Sweden).

We simulate the distribution of fiscal limits by setting the average political parameter to 0.86 , the persistence of productivity shock to 0.6 and the standard deviation to 0.018 . All of the fiscal variables are calibrated to match the data. The bottom panel of Figure 4 illustrates that a large fiscal transfer program generates small fiscal margins for maneuver and places a short leash on the level of government debt.

\section{Sovereign Risk Premia: Nonlinear Solution}

In this section, we calibrate the model to the economy of Greece and then solve the nonlinear model. Due to the existence of a fiscal limit, the model can not be solved through linearization. Instead, we resort to the Monotone Mapping method in order to solve the model nonlinearly.

4.1 Method The solution method, based on Coleman (1991) and Davig (2004), conjectures candidate decision rules that reduce the system to a set of expectation first-order difference equations. In this model, the decision rule maps the current state, denoted as $\psi_{t}=\left\{b_{t}^{d}, A_{t}, g_{t}\right\}$, into the value of government debt $\left(b_{t}\right) .^{5}$ The mapping is denoted as $b_{t}=f^{b}\left(\psi_{t}\right)$.

The complete model consists of a system of nonlinear equations including the first-order conditions from the household's maximization problem, Equations 9 and 10; the government budget constraint, Equation 3; the specifications of the policy process, Equations 4; the

\footnotetext{
${ }^{5}$ Note the state variable $b_{t}^{d}=\left(1-\Delta_{t}\right) b_{t-1}$ incorporates 2-dimension information: the effective fiscal limit at time $\mathrm{t}, b_{t}^{*}$, and the pre-default government liability, $b_{t-1}$.
} 
aggregate resource constraint, Equation 1; the specifications of shock processes, Equation 2 and 6; the transversality condition, Equation 11; and the specification of the default scheme, Equation 12.

After substituting into the conjectured rule, the core equation of the model is,

$$
\begin{array}{r}
\frac{b_{t}^{d}+g_{t}+z\left(\psi_{t}\right)-\tau\left(\psi_{t}\right) A_{t}\left(1-L\left(\psi_{t}\right)\right)}{f^{b}\left(\psi_{t}\right)} \\
=\beta E_{t}\left\{\left(1-\Delta\left(f^{b}\left(\psi_{t}\right), A_{t+1}, g_{t+1}, b_{t+1}^{*}\right)\right) \frac{u_{c}\left(f^{b}\left(\psi_{t}\right), A_{t+1}, g_{t+1}, b_{t+1}^{*}\right)}{u_{c}\left(\psi_{t}\right)}\right\}
\end{array}
$$

The expectation in the right-hand side is evaluated using a numerical quadrature. Equation 14 is solved for each set of state variables defined over a discrete partition of the state space. The decision rule $\left(f^{b}(\psi)\right)$ is updated at every node in the state space. The procedure is repeated until the iterations update the current decision rule by less than some $\epsilon>0$ (set to $1 e-8)$.

After finding the decision rule for government bonds $\left(f^{b}(\psi)\right)$ I can solve the pricing rule ( $q=f^{q}(\psi)$ ) using the government budget constraint, Equation 3. The interest rate on government bonds can also be solved using $R_{t}=\frac{1}{q_{t}}$, denoted as $f^{R}(\psi)$.

\subsection{Calibration to the Economy of Greece The fiscal parameters are calibrated} in order to match the Greek data from 1971 to 2007. At the steady state, the government purchases are set to $16.7 \%$ of the GDP, the lump-sum transfers to $13.34 \%$ of the GDP, and the government debt to $40 \%$ of the GDP. ${ }^{6}$ The resulting tax rate is 0.32 at the steady state, which is slightly higher than the average tax rate of 0.28 . The estimated elasticity of real detrended lump-sum transfers with respect to real GDP per worker $\left(\zeta^{z}\right)$ is -0.45 . The tax adjustment parameter $\gamma$ is estimated at $0.42 .^{7}$

The ICRG index of political risk for Greece represents a regime-switching process. It stayed low and stable during the period between 1984 and 1993, rose from the level of around 60 to 80 between 1994 and 1996, and stayed around the high level until the financial crisis erupted in 2008. The regime switching in the middle 1990s was related to the establishment of the European Union, while the recent switching is related to the political uncertainty of the European Union bail-out plan in the wake of financial crisis. In this model, we calibrate $\theta_{t}$ as a two-state symmetric Markov regime switching process. The low state $\theta_{L}$ is calibrated to 0.61 , the average ICRG index of political risk from 1984 to 1993 scaled by 100, and the

\footnotetext{
${ }^{6}$ The data of government debt is from European Commission (2009).

${ }^{7} \gamma$ is estimated through linear regression of the tax rate over government debt-GDP ratio during the period of 1971 to 1995, because the debt-GDP ratio for Greece governemnt is almost flat from 1995 to 2007.
} 
high state $\theta_{H}$ is 0.78 , the average ICRG index from 1994 to 2007 scaled by 100 . We assume that the probability of a switch between the two states is $1 / 13$, as Greece enjoyed a stable and high ICRG index within 13 years from 1994 to 2007.

Using HP filter, the productivity shock has a persistence of 0.45 and standard deviation of 0.0328 , while the government purchase shock has a persistence of 0.426 and standard deviation of 0.0294. All of the other parameters are calibrated in the same way as the benchmark calibration in Section 3.1.

We simulate the distribution of the fiscal limit according to the above calibrations. Figure 5 shows that the distribution is more dispersed if the political risk is a Markov-regime switching process than if fixed at either low or high level. We focus on the Markov-regime switching case. The mean of the distribution $\left(b^{*}\right)$ is 0.4251 , around $170 \%$ of the GDP, and the standard deviation $\left(\sigma_{b}\right)$ is 0.0267 . Following the default scheme in Section 2.2, the default rate $(\delta)$ is 0.1256 .

4.3 Decision Rule The pricing rule of the government bond interest rate maps a 3dimension state space to a 1 -dimension state space, $R_{t}=f^{R}\left(b_{t}^{d}, A_{t}, g_{t}\right)$. The rule is a 4-dimension surface in a single graph. For simplicity, we have plotted slices of the surface by fixing two variables at a time.

By keeping the government purchases $\left(g_{t}\right)$ at the steady state, the top panel of Figure 6 compares the response of net interest rate to the current government liability $b_{t}^{d}$ under different values of productivity $\left(A_{t}\right)$. The two green vertical lines, labeled $b^{*}$ and $b_{2 s t d}^{*}$, are the mean of the fiscal limit and the threshold that is lower than the mean by two standard deviations $\left(b_{2 s t d}^{*}=b^{*}-2 \sigma_{b}\right)$, respectively. The dashed red, solid blue, and dashed-dotted black line represent the responses in interest rate when the level of productivity is respectively two standard deviations lower than the steady state (Low $A$ ), at steady state, and two standard deviations higher than the steady state (High $A$ ). Two findings follow from the comparison. First, the net interest rate rises with government liability in a nonlinear way. In all three cases the interest rate rises sharply as government liability enters the lower end of the distribution of the fiscal limit, i.e. $b_{t}^{d}$ is larger than $b_{2 s t d}^{*}$. The financial market starts to demand a premium for the government bond as the probability of sovereign default begins to emerge from nil. Second, the level of productivity has a substantial impact on default risk premia. For a given level of current government liability, the lower the level of productivity, the higher the interest rate, i.e. the dashed red line lies above the dashed-dotted black line. In a recession, tax revenue is slashed and the government has to issue more debt in order to finance its expenditures. A higher debt level can substantially raise the sovereign default probability and risk premium of the government bond. 
The bottom panel of Figure 6 compares the responses of the interest rate to the current government liability under different levels of government purchases $\left(g_{t}\right)$ while keeping the level of productivity $\left(A_{t}\right)$ at the steady state. Again, the interest rate rises sharply as government liability enters the lower end of the distribution of the fiscal limit. However, different government purchases do not have much of an impact on the interest rates as the dashed, solid and dashed-dotted lines are very close. Government purchases affect the level of government debt in two opposite directions. Higher expenditures drive up government liability, while crowding out private consumption. Thereofre, the household may work more due to an income effect. A higher output raises tax revenues and helps to finance government purchases. Overall, different government purchases do not have a significant impact on the interest rate due to the logarithmic utility function.

\subsection{Nonlinear Simulation Figure (7) illustrates the nonlinear simulation in which we} draw a sequence of positive government spending shocks and negative productivity shocks. At the period $t=1$, the government debt is set to $125 \%$ of the GDP, similar to the debt level that the Greek government accumulates by 2009. In the following five periods, the economy receives shocks from government purchases and the level of productivity. The simulated paths of productivity and government purchases over the GDP ratio, summarized in Table 4.4, are meant to capture the countercyclical fiscal policies in a severe economic downturn.

\begin{tabular}{ccccccc}
\hline \hline & $\mathrm{t}=1$ & $\mathrm{t}=2$ & $\mathrm{t}=3$ & $\mathrm{t}=4$ & $\mathrm{t}=5$ & $\mathrm{t}=6$ \\
\hline Productivity & $-4.88 \%$ & $-8.61 \%$ & $-9.97 \%$ & $-6.67 \%$ & $-4.21 \%$ & $-1.92 \%$ \\
Government Spending-GDP & $20.35 \%$ & $21.68 \%$ & $21.81 \%$ & $21.08 \%$ & $20.29 \%$ & $19.52 \%$ \\
\hline \hline
\end{tabular}

As shown in Figure 7, the household works less and consumes less when the productivity is low. The lower tax revenue, as a result of a lower labor supply and productivity, and higher government purchases push up the government's borrowing. Interest rates rise partly because households substitute away from future consumption and partly because government liability approaches the effective fiscal limit (the green line $b_{t}^{*}$ ) which is randomly drawn from the distribution of the fiscal limit, $\mathcal{N}\left(b^{*}, \sigma_{b}^{2}\right)$. The government budget is further deteriorated through rising interest payments.

In order to disentangle the effect of the intertemporal substitution from the risk premium in the rising interest rate, Figure 7 compares the default model with a default-free economy in which the sovereign bond is not constrained by the fiscal limit and $\delta$ is zero. ${ }^{8}$ The solid black lines represent the default model, while the dashed blue lines represent the defaultfree economy under the same sequences of shocks. The risk premium of a one-period bond,

\footnotetext{
${ }^{8}$ The default-free case can be interpreted as the economy with access to lump-sum taxes.
} 
defined as the interest rate difference between the two economies, is around 80 basis points for a prolonged period.

4.5 LONG-TERM BOND In practice, the interest rate spreads of long-term bonds, rather than short-term bonds, are used to measure sovereign default risk premia. An n-period bond can be priced as,

$$
Q_{t}^{n}=\beta^{n} E_{t}\left(\left(1-\Delta_{t+n}\right) \frac{u_{c}(t+n)}{u_{c}(t)}\right) .
$$

The multiple-period expectation is calculated using MCMC simulation. We use a finiteelement method to approximate the decision rules of a one-period bond.

Conditional on the same shocks as in Figure 7, Figure 8 illustrates that the premia of the long-term bonds jump ahead of the short-term bond and provide early warnings of sovereign defaults. Expected high government indebtedness in the future results in a rise in current risk premia of long-term bonds, even the risk premia of short-term bonds are flat. The longer the bond maturity, the earlier the default risk premia begin to emerge.

\section{CONCLUSion}

This paper presents a general equilibrium framework in which an endogenous and stochastic fiscal limit measures the government's ability and willingness to service its debt. The fiscal limit is constrained by the dynamic Laffer Curves, implied by distorting taxes, and, also, depends on political willingness. The distribution of fiscal limits depends on the underlying economic fundamentals, for instance, the size of the government, the degree of the countercyclical fiscal policy, economic diversity and political uncertainty. Calibrated to different countries, the model predicts distributions of fiscal limits consistent with the observed sovereign ratings in OECD countries.

Due to the existence of fiscal limits, the model produces a nonlinear relationship between the default risk premia and the level of government debt. The risk premia start to emerge as the level of debt approaches the fiscal limit. In addition, long-term bonds give early warnings of sovereign defaults. The longer the bond maturity, the earlier the default risk premium emerges. 


\section{REFERENCES}

Alesina, A., De Broeck, M., Prati, A. and Tabellini, G. (1992). Default risk on government debt in oecd countries. Economic Policy, 7 (15), 428-463.

Arellano, C. (2008). Default risk and income fluctuations in emerging economies. American Economic Review, 98 (3), 690-712.

Arteta, C. and Galina, H. (2008). Sovereign debt crises and credit to the private sector. Journal of International Economics, 74, 53-69.

Bernoth, K., von Hagen, J. and Schuknecht, L. (2006). Sovereign risk premiums in the european government bond market. GESY Discussion Paper No. 151.

Cochrane, J. (2010). Understanding fiscal and monetary policy in the great recession. Manuscript, Chicago University.

Coleman, I., Wilbur John (1991). Equilibrium in a production economy with an income tax. Econometrica, 59, 1091-1104.

Davig, T. (2004). Regime-switching debt and taxation. Journal of Monetary Economics, $51(4), 837-859$.

Eaton, J. and Gersovitz, M. (1981). Debt with potential repudiation: Theoretical and empirical analysis. Review of Economic Studies, 48 (2), 289-309.

Heston, A., Summers, R. and Aten, B. (2006). Penn World Table Version 6.2. Tech. rep., Center for International Comparisons of Production, University of Pennsylvania.

Hodrick, R. J. and Prescott, E. C. (1997). Postwar u.s. business cycles: An empirical investigation. Journal of Money, Credit and Banking, 29 (1), 1-16.

Juessen, F., Linnemann, L. and Schabert, A. (2009). Default risk premia on government bonds in a quantitative macroeconomic model. Tinbergen Institute Discussing Papers, 09-102/2.

LeEPer, E. M. (1991). Equilibria under 'active' and 'passive' monetary and fiscal policies. Journal of Monetary Economics, 27 (1), 129-147.

Poor's, S. . (2008). Sovereign Credit Ratings: A Primer. Tech. rep.

Reinhart, C. M. and Rogoff, K. (2009). This Time is Different: Eight Centuries of Financial Folly. Princeton University Press. 
Trabandt, M. and Uhlig, H. (2009). How far are we from the slippery slope? the laffer curve revisited. NBER Working Paper, No. 15343.

URIBE, M. (2006). A fiscal theory of sovereign risk. Journal of Monetary Economics, 53, $1857-1875$. 


\section{A Simulation of Fiscal Limit}

In this model, household consumption and labor supply only depend on the income tax rate and the exogenous state variables $(A, g)$. Assume the utility function is $u(c, L)=$ $\log c+\phi \log L$. Household first-order conditions can be written as,

$$
\begin{aligned}
1-L_{t} & =\frac{A_{t}\left(1-\tau_{t}\right)+\phi g_{t}}{A_{t}\left(1+\phi-\tau_{t}\right)} \\
c_{t} & =\frac{\left(A_{t}-g_{t}\right)\left(1-\tau_{t}\right)}{1+\phi-\tau_{t}}
\end{aligned}
$$

The tax revenue $\left(T_{t}\right)$ is,

$$
\begin{aligned}
T_{t} & =\tau_{t} \frac{A_{t}\left(1-\tau_{t}\right)+\phi g_{t}}{1+\phi-\tau_{t}} \\
& =(1+2 \phi) A_{t}-\phi g_{t}-\left(A_{t}\left(1+\phi-\tau_{t}\right)+\frac{(1+\phi) \phi\left(A_{t}-g_{t}\right)}{1+\phi-\tau_{t}}\right)
\end{aligned}
$$

The tax revenue reaches to the maximum level $\left(T_{t}^{\max }\right)$ if the tax rate reaches the peak point of the Laffer Curve $\left(\tau_{t}^{\max }\right)$.

$$
\begin{aligned}
\tau_{t}^{\max } & =1+\phi-\sqrt{\frac{(1+\phi) \phi\left(A_{t}-g_{t}\right)}{A_{t}}} \\
T_{t}^{\max } & =(1+2 \phi) A_{t}-\phi g_{t}-2 \sqrt{(1+\phi) \phi A_{t}\left(A_{t}-g_{t}\right)}
\end{aligned}
$$

Since there exists a unique mapping between the exogenous state space $(A, g)$ to $\tau^{\max }$ and $T^{\max }$, the fiscal limit $\left(\mathcal{B}_{0}^{*}\right)$ can be obtained using Markov Chain Monte Carlo simulation and be approximated as a normal distribution. We draw 300 realizations of the productivity and government purchase shocks and compute the paths for all the variables in the model under the assumption that the tax rate is at the peak of the Laffer Curve. We discard the first 200 draws as a burn-in period and compute the discounted sum of future surpluses, according to Equation 13. We then repeat this 10000 times and plot the resulting distribution. 

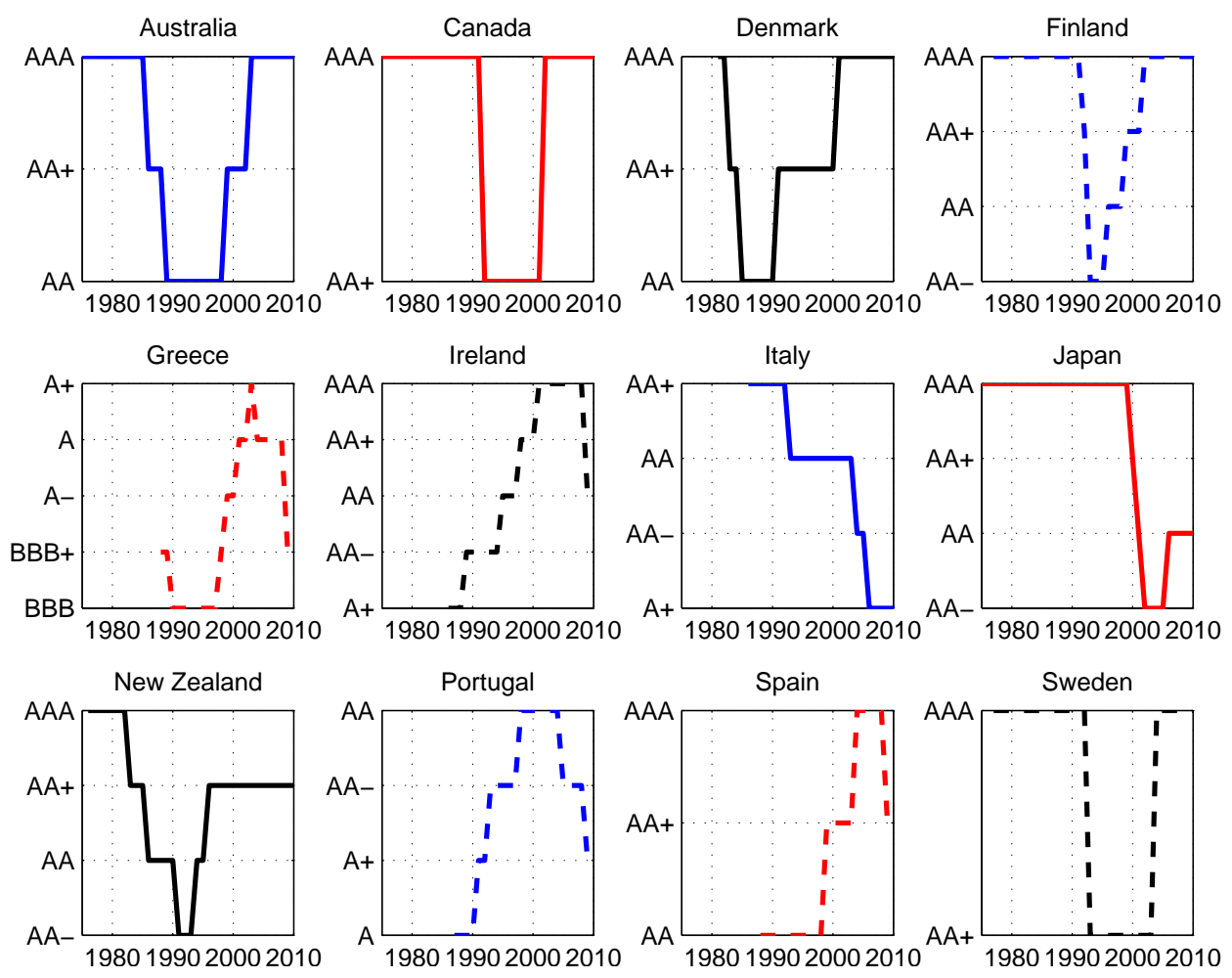

Figure 1: Sovereign downgrades in OECD countries from 1975 to 2010 (Standard \& Poor's 

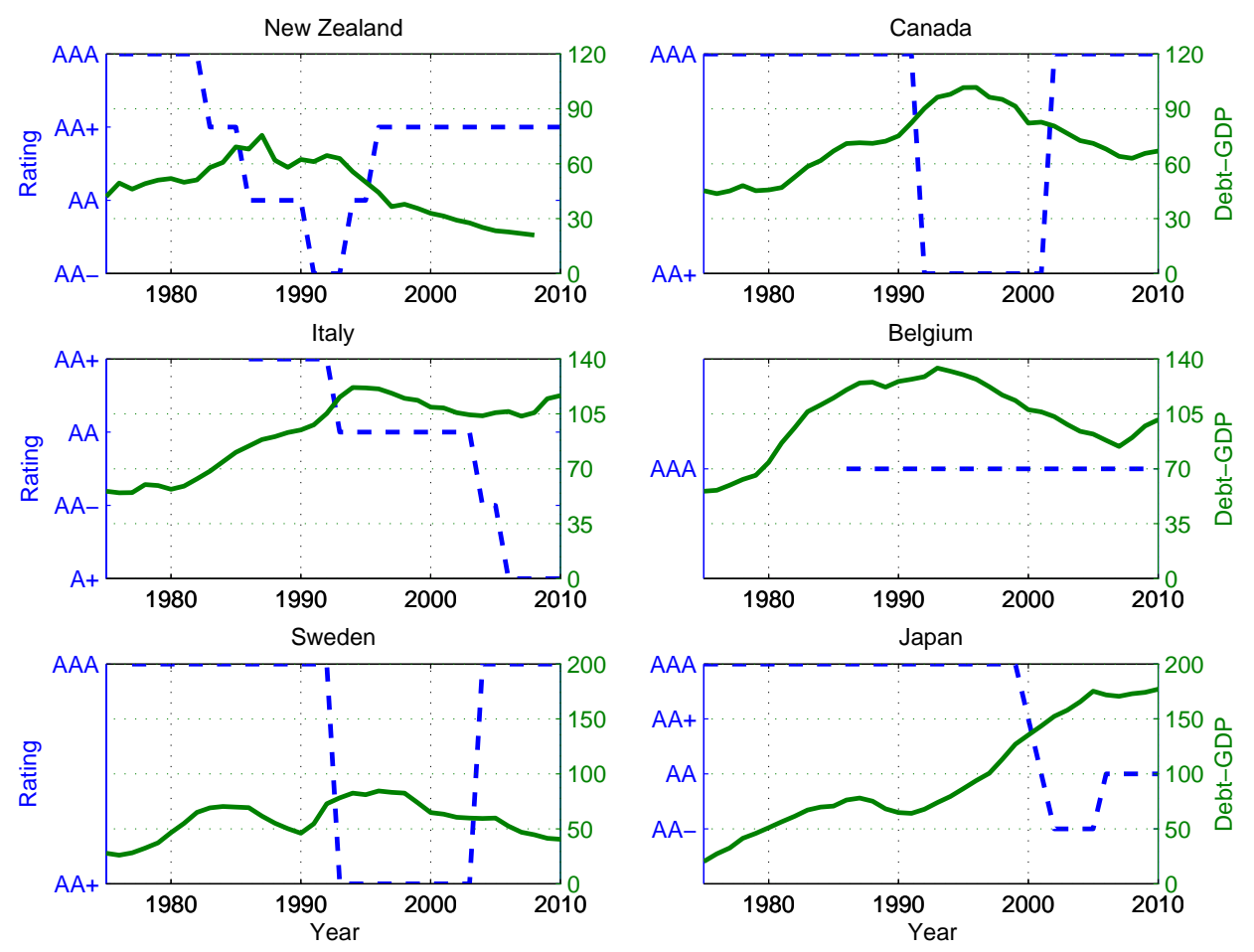

Figure 2: Comparison of sovereign downgrades (dashed blue line, measured to the left axis) and government debt-GDP ratio (solid green line, measured to the right axis) in selected countries during the period of 1975 to 2010. 

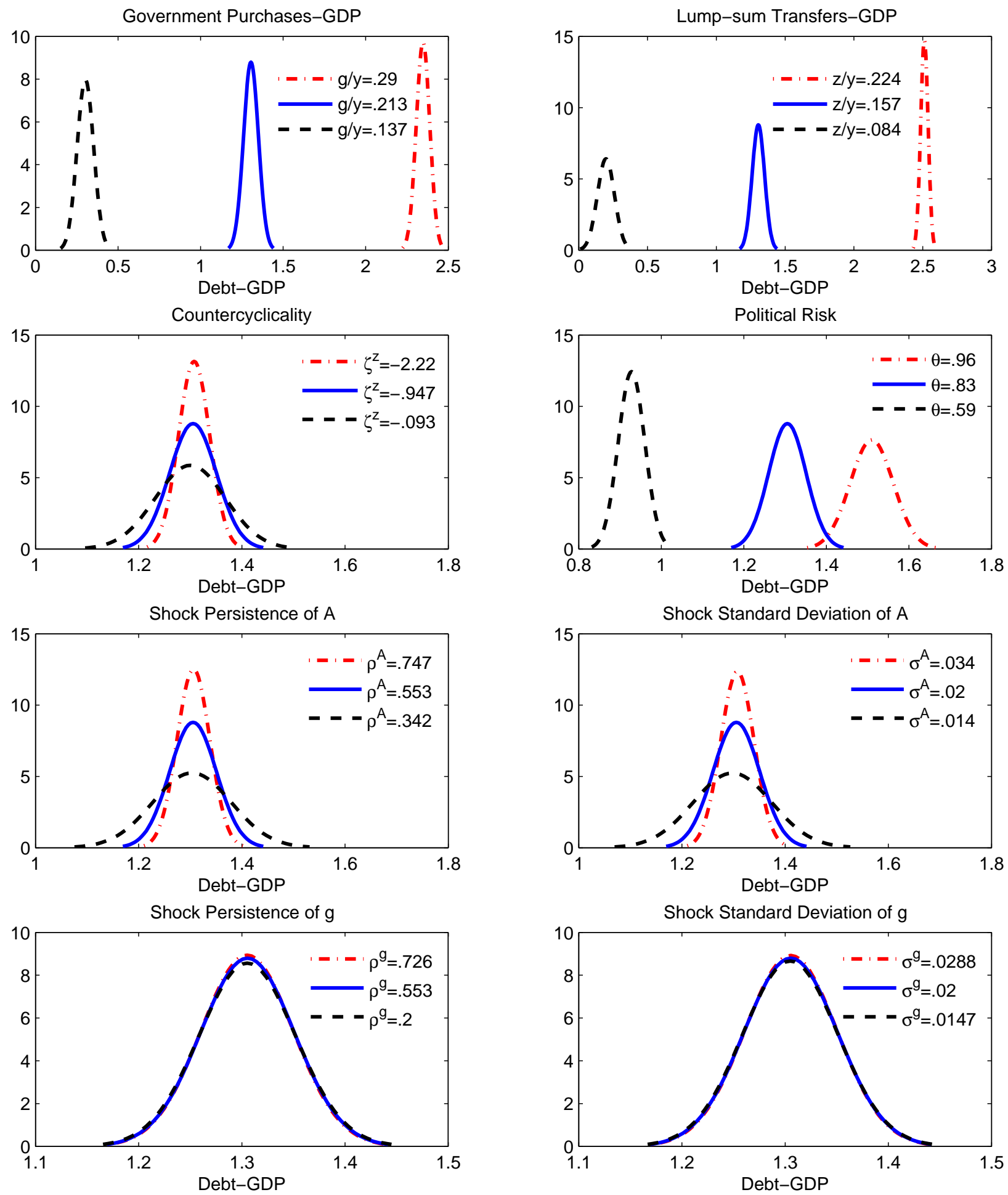

Figure 3: Comparison of the distribution of fiscal limits as one parameter changes in each panel. The middle distribution in each panel is under the benchmark calibration. 

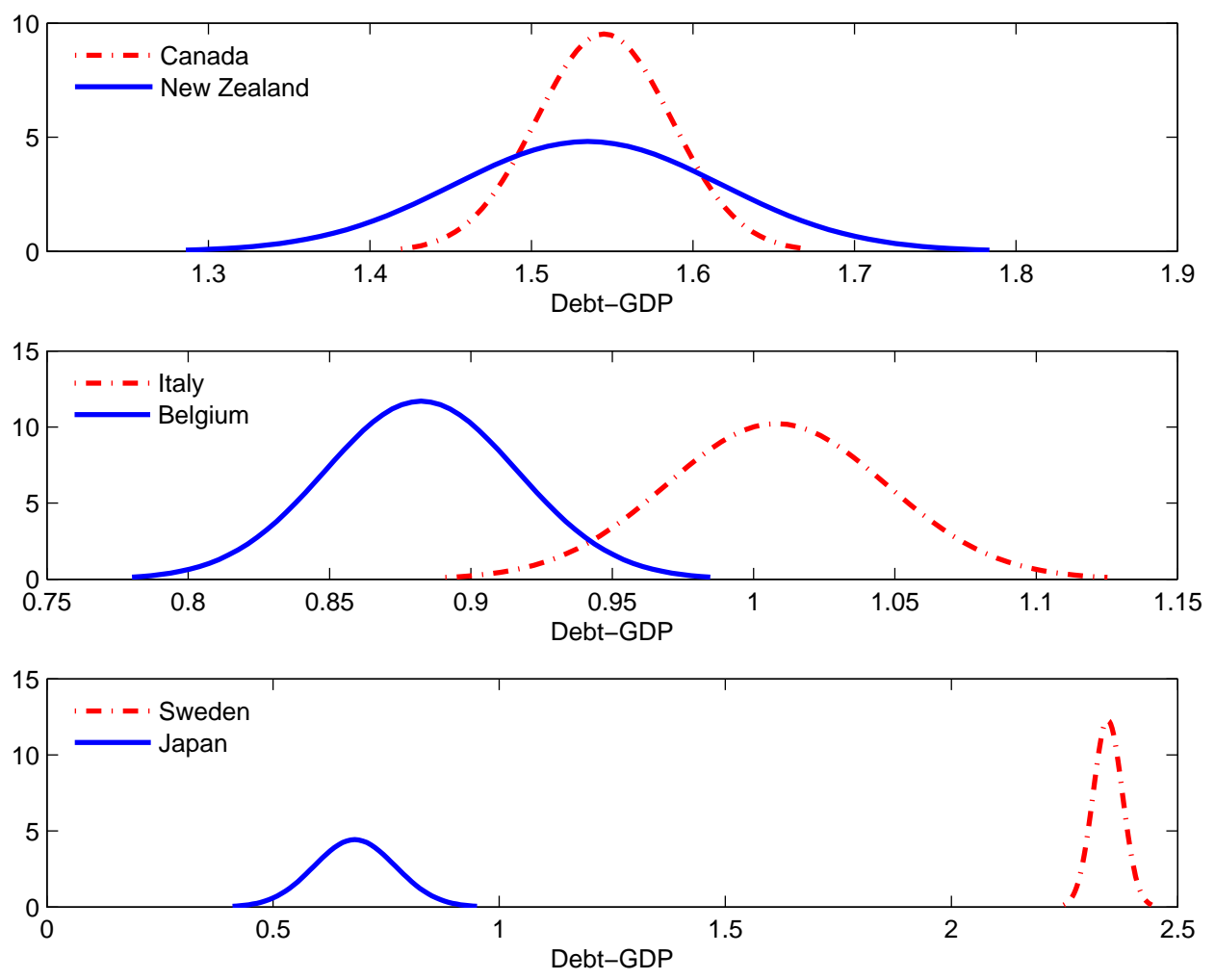

Figure 4: Comparison of the distribution of fiscal limits in different country groups: top panel (New Zealand vs. Canada); middle panel (Italy vs. Belgium); bottom panel (Sweden vs. Japan). 


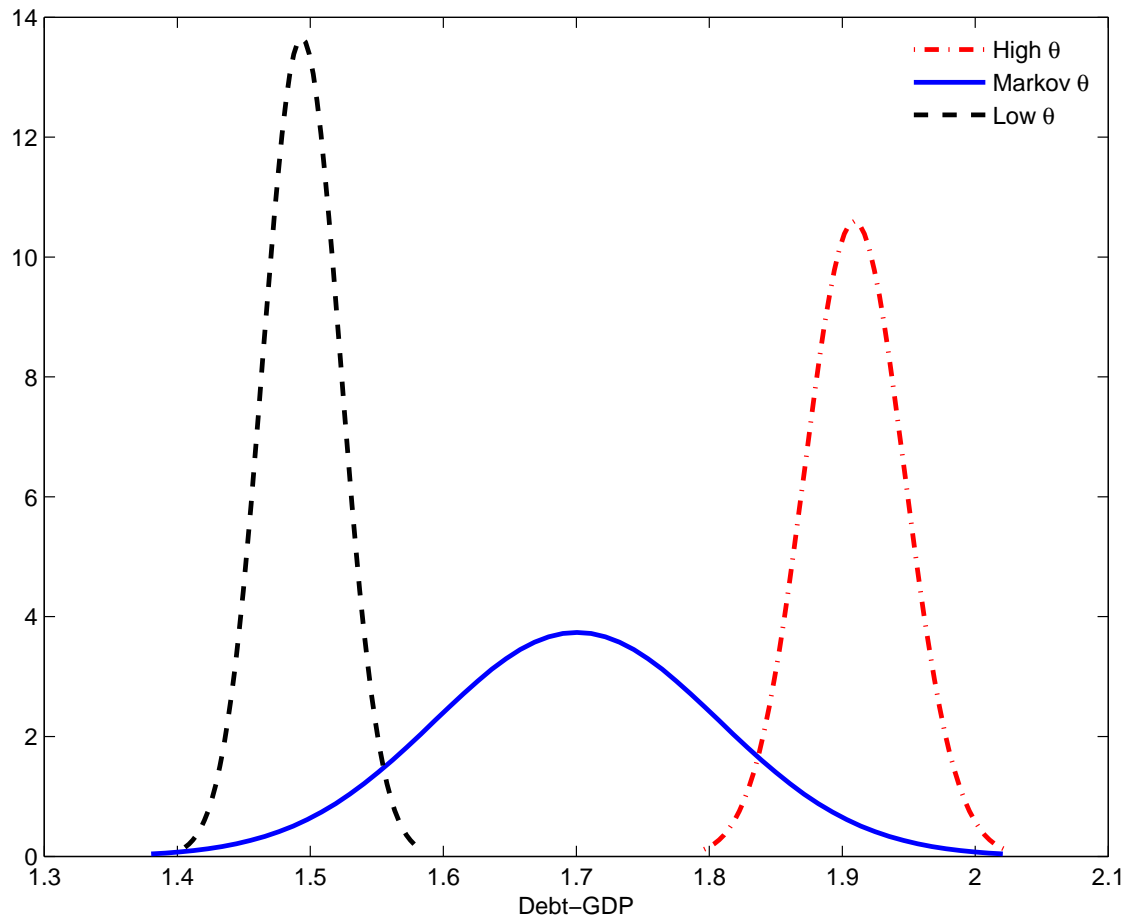

Figure 5: Simulated distribution of fiscal limit in Greece 
$r(b)$ with $g$ at Steady State under Different $A$

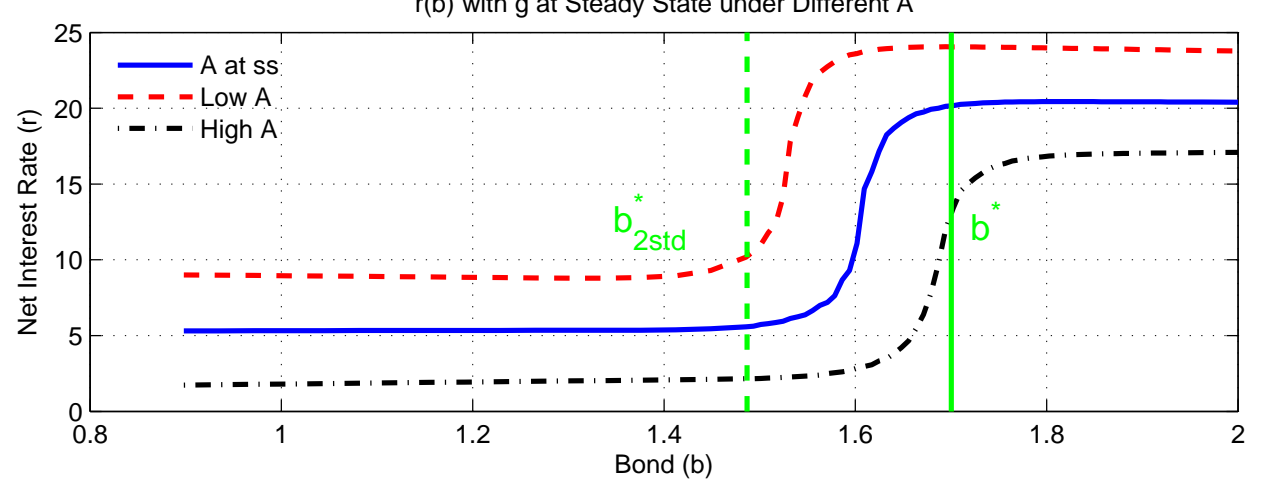

$r(b)$ with $A$ at Steady State under Different $g$

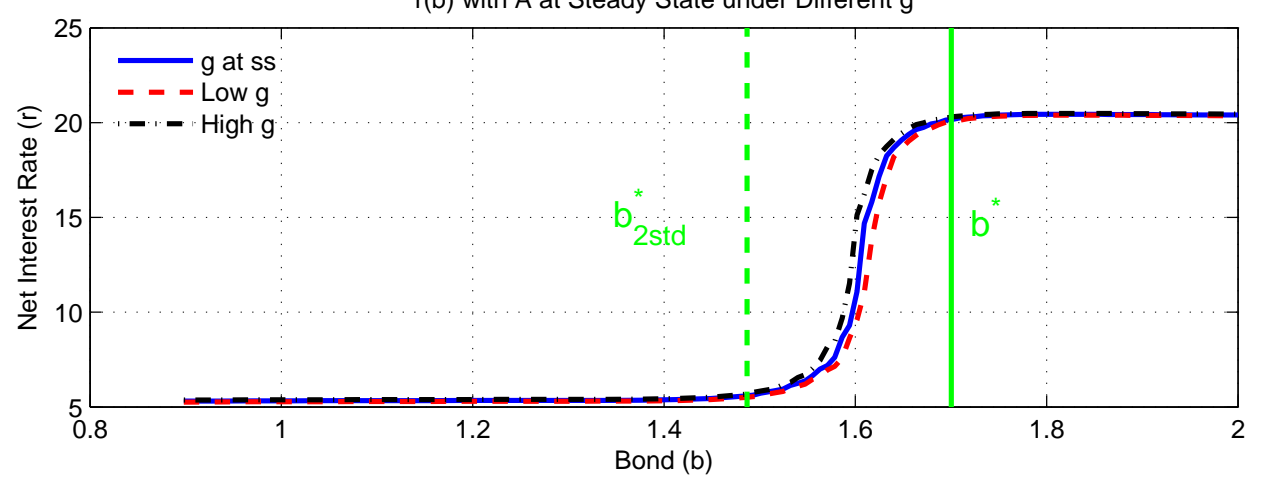

Figure 6: Pricing rule of net interest rater $(b)=(R(b)-1) * 100$ : top panel compares the pricing rule at a high, steady-state, and low level of $A$ while $g$ is at steady state; bottom panel compares the rule at a high, steady-state, and low level of $g$ while $A$ is at steady state. 

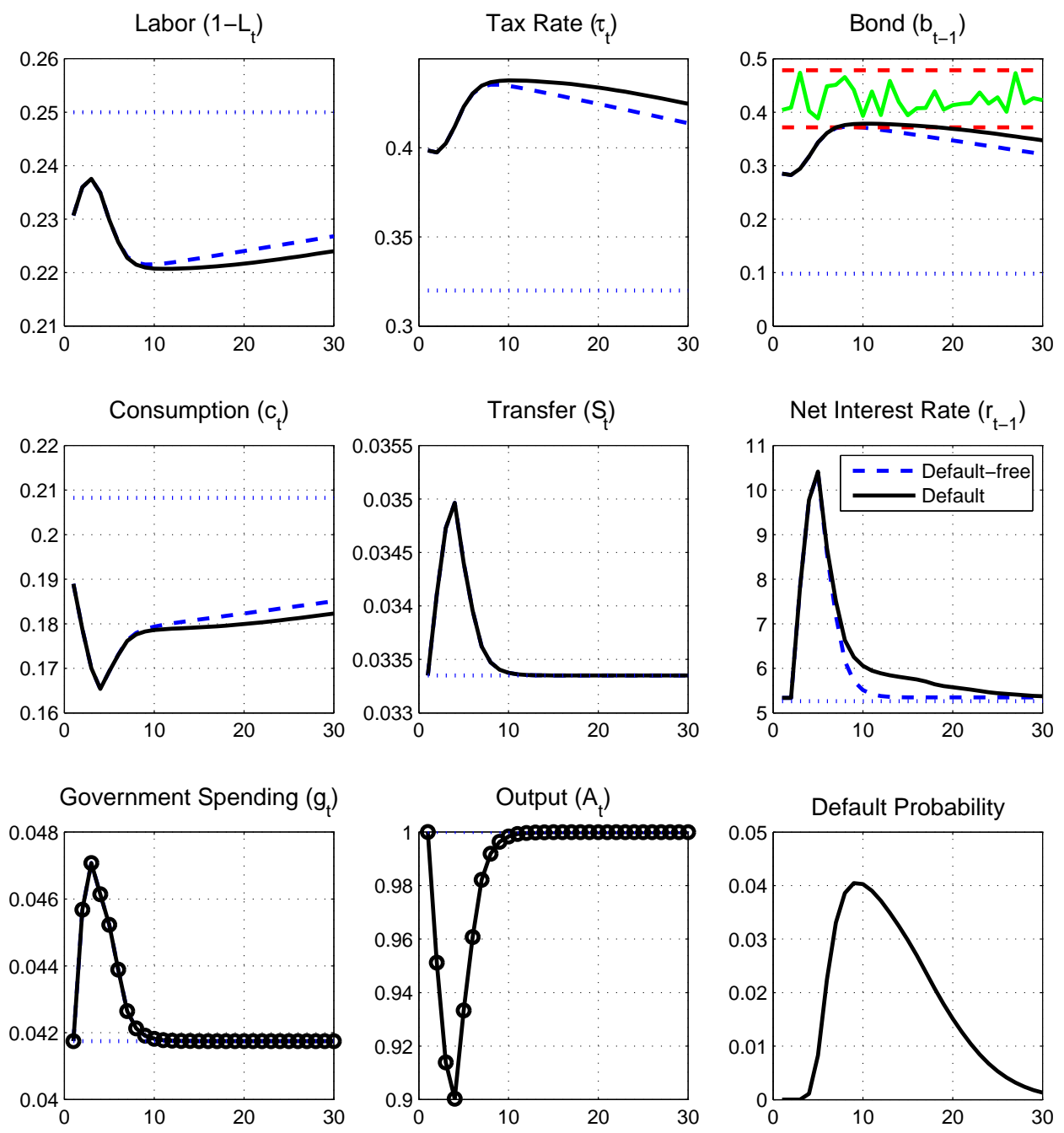

Figure 7: Nonlinear simulation to negative productivity shocks combined with positive government purchase shocks: stochastic default case (solid black line) vs. default-free case (dashed blue line). 


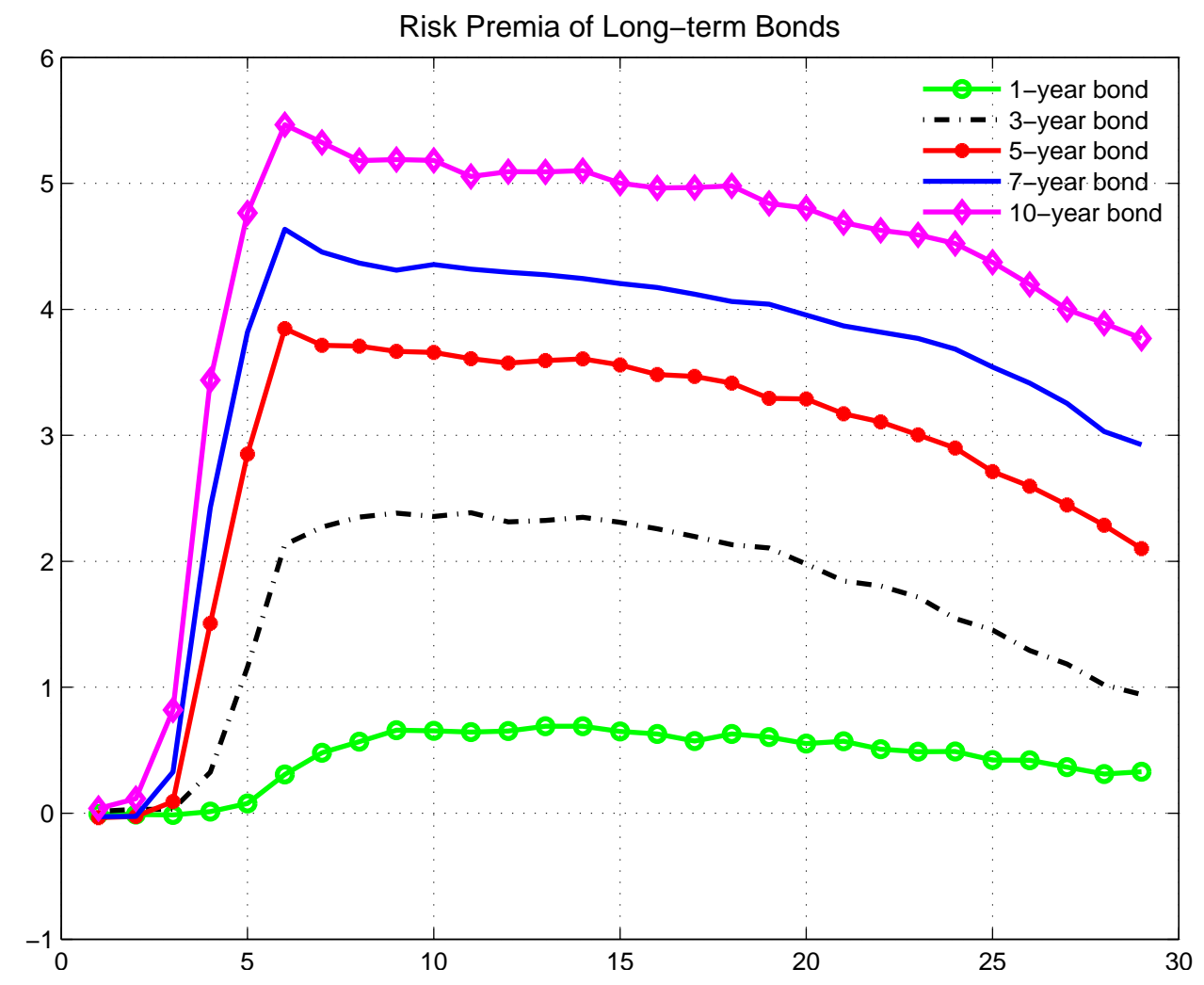

Figure 8: Risk premia of long-term bond with different maturities conditional on the shock paths in Figure 7. 